\title{
Identification of inflammatory phenotypes of asthma by blood analysis and clinical parameters
}

\author{
Bart Hilvering $^{1 *}$, Rene Schweizer ${ }^{2}$, Jan-Willem Lammers ${ }^{2}$, Leo Koenderman ${ }^{2}$ \\ From EAACI International Severe Asthma Forum (ISAF 2012) \\ Gothenburg, Sweden. 11-13 October 2012
}

\section{Background}

Identification of an inflammatory asthma phenotype currently requires sputum induction. This technique is invasive, has a high variability, is time-consuming and a burden for patients. Therefore, there is a strong need for a routine blood test to establish the inflammatory phenotype of asthma. We designed a clinical cohort study (AIR-study, NCT01611012) in 115 asthma patients visiting the outpatient clinic to compare the results of such a blood test to sputum analysis. This abstracts focuses at the preliminary results in 21 patients.

\section{Objective}

To assess whether expression of active FcgammaRII (CD32) and MAC-1( CD11b) on neutrophils and eosinophils in peripheral blood enables the diagnosis of an inflammatory phenotype of asthma.

\section{Materials and methods}

21 asthma patients were recruited at the outpatient clinic of the University Medical Centre Utrecht. Clinical parameters were gathered and FENO (fractional exhaled nitric oxide), sputum induction and blood tests were performed. Eosinophils and neutrophils in whole blood were stained with a FITC labeled antibody against active FcgammaRII receptor (clone A17) and a PE-labeled antibody against $\mathrm{CD} 11 \mathrm{~b}$ in the absence and presence of the activator fMLP $(1 \mu \mathrm{M})$. Subsequently, fluorescence intensity was measured by flowcytometry.

\section{Preliminary results}

Expression of Mac-1 (CD11b) and activeFcgammaRII (CD32) on eosinophils at basal level and after stimulation (fMLP) showed refractory cells (low responsiveness for fMLP) in case of granulocytic asthma (neutrophilic,

${ }^{1}$ UMC Utrecht, the Netherlands

Full list of author information is available at the end of the article eosinophilic and mixed phenotype). FENO values were overall lower in paucigranulocytic asthma compared to granulocytic asthma ( $\mathrm{p}=0.009$, independent $\mathrm{t}$-test).

\section{Conclusion}

Refractory blood eosinophils determined by a simple blood test were found in those patients that were more likely to suffer from granulocytic asthma (diagnosis by sputum analysis). Therefore, paucigranulocytic asthma can be distinguished from other phenotypes purely based on blood analysis and FENO measurement. A low expression of activation epitopes on eosinophils in peripheral blood might indicate that 'activation prone' eosinophils migrated to the lung.

\section{Author details}

'UMC Utrecht, the Netherlands. ${ }^{2}$ UMC Utrecht, Respiratory Medicine, the Netherlands.

Published: 3 May 2013

doi:10.1186/2045-7022-3-S1-09

Cite this article as: Hilvering et al:. Identification of inflammatory phenotypes of asthma by blood analysis and clinical parameters. Clinical and Translational Allergy 2013 3(Suppl 1):09.

Submit your next manuscript to BioMed Central and take full advantage of:

- Convenient online submission

- Thorough peer review

- No space constraints or color figure charges

- Immediate publication on acceptance

- Inclusion in PubMed, CAS, Scopus and Google Scholar

- Research which is freely available for redistribution

\section{Ciomed Central}

